\title{
Molecular forms of myeloperoxidase in human plasma
}

\author{
Ragnar L. OLSEN, Terje K. STEIGEN, Turid HOLM and Clive LITTLE* \\ Institute of Medical Biology, University of Tromsø, P.O. Box 977, N-9001 Tromsø, Norway
}

1. A radioimmunoassay for myeloperoxidase was established with the use of affinity-purified anti-(human myeloperoxidase) immunoglobulins. 2. By the use of ion-exchange followed by immunoaffinity chromatography a preparation of immunoreactive, catalytically active myeloperoxidase was obtained from fresh human plasma. 3. In non-denaturing gel electrophoresis, the plasma preparation showed about four catalytically active components of mobility very similar to that of the granulocyte enzyme. 4 . SDS/polyacrylamide-gel electrophoresis combined with protein blotting showed that the two polypeptides of strongest antigenicity in the plasma preparation corresponded in $M_{\mathrm{r}}$ to the large and the small subunits of the granulocyte enzyme. In addition, the plasma preparation contained a higher- $M_{\mathrm{r}}$ immunoreactive polypeptide, possibly a precursor form of the enzyme, together with another of $M_{\mathrm{r}}$ similar to that of the large subunit of eosinophil peroxidase.

\section{INTRODUCTION}

Studies in several laboratories indicate that lysosomal enzymes are synthesized as precursors and processed to mature forms during or subsequent to storage in the lysosomes (Erickson \& Blobel, 1979; Hasilik \& Neufeld, 1980; Skudlarek \& Swank, 1981; Sly \& Fischer, 1982; Hasilik et al., 1983). In culture of cells such as fibroblasts (Hasilik \& Neufeld, 1980), endothelial cells and smoothmuscle cells (Hasilik et al., 1981), a small portion of the synthesized lysosomal enzymes escapes segregation into the lysosomes and is secreted as high- $M_{\mathrm{r}}$ precursors. Under normal conditions cultures of monocytes and macrophages release small amounts of precursor forms of lysosomal enzymes (Imort et al., 1983), and upon stimulation mature lysosomal enzymes are secreted (reviewed by Page et al., 1978). Neutrophil granulocytes have also been shown upon stimulation to secrete granule constituents (Henson, 1971; Bentwood \& Henson, 1980). One lysosomal enzyme in neutrophil granulocytes is myeloperoxidase (MPO), and it has been shown by Bradley et al. (1982) that neutrophils migrating to sites of inflammation release active MPO.

MPO is present in the azurophil (primary) granules and is synthesized at the promyelocyte stage (Bainton et al., 1971 ; Spitznagel et al., 1974; Yamada, 1982). The enzyme is a haem-containing glycoprotein shown to be a tetramer composed of two pairs of subunits with $M_{\mathrm{r}}$ values of 57000 and 10500 (Olsson et al., 1972; Andrews \& Krinsky, 1981; Andersen et al., 1982; Olsen \& Little, 1984). In the promyelocyte cell line HL-60 it has been shown that MPO is synthesized as a precursor with an $M_{\mathrm{r}}$ of 89000 and subsequently processed to mature subunits of similar size to those found in the normal leucocytes (Yamada, 1982; Hasilik et al., 1984; Olsson et al., 1984). These studies performed in vitro also show that only the high- $M_{\mathrm{r}}$ precursor is secreted into the culture medium.

MPO, as measured by radioimmunoassay in plasma, has been shown to correlate with the number of neutrophils present in the blood (Hansen et al., 1975). Several reports on the amounts of MPO in plasma and serum under normal and pathological conditions have been published (Malmquist, 1972; Olsson et al., 1979; Öberg \& Venge, 1982; Venge et al., 1984).

In the present paper we report the purification of immunoreactive MPO from normal human plasma by the use of ion-exchange and immunoaffinity chromatography. Electrophoresis and protein blotting were used to examine the molecular forms of plasma enzyme.

\section{MATERIALS AND METHODS}

\section{Materials}

Plasma from citrated fresh human blood was obtained by centrifugation at $3500 \mathrm{~g}$ for $12 \mathrm{~min}$. To eliminate contaminating "cells the centrifugation was repeated before storage of the plasma at $-28^{\circ} \mathrm{C}$. CM-Sephadex C-50 and Sepharose 4B were obtained from Pharmacia, Uppsala, Sweden. Sources of other chemicals and biochemicals are indicated in the text.

\section{Immunoglobulins and immunoaffinity columns}

Rabbit antiserum was raised against purified human MPO essentially by a method described previously (Olsen \& Little, 1982). The anti-MPO immunoglobulins were isolated from the antiserum by using purified MPO immobilized on CNBr-activated Sepharose 4B. The procedure for coupling to the $\mathrm{CNBr}$-actived Sepharose was basically as recommended in the Pharmacia booklet Affinity Chromatography (Pharmacia Fine Chemicals, Uppsala, Sweden).

MPO-Sepharose (24 ml gel) containing approx. $1.5 \mathrm{mg}$ of $\mathrm{MPO} / \mathrm{ml}$ of gel, in $0.15 \mathrm{M}-\mathrm{NaCl} / 50 \mathrm{mM}$-Tris $/ \mathrm{HCl}$ buffer, $\mathrm{pH} 7.4$, was mixed with $20 \mathrm{ml}$ of antiserum for $2 \mathrm{~h}$ at $4{ }^{\circ} \mathrm{C}$. The gel was then washed in a column with $0.15 \mathrm{M}-\mathrm{NaCl} / 50 \mathrm{~mm}-\mathrm{Tris} / \mathrm{HCl}$ buffer, $\mathrm{pH} 7.4$, and subsequently $0.5 \mathrm{M}-\mathrm{NaCl} / 50 \mathrm{~mm}$-Tris/HCl buffer, $\mathrm{pH}$ 7.4. The anti-MPO immunoglobulins were eluted by 0.5 M- 
$\mathrm{NaCl} / 0.1 \mathrm{M}$-glycine/ $\mathrm{HCl}$ buffer, $\mathrm{pH} 2.5$. The $\mathrm{pH}$ of the eluted fractions $(5 \mathrm{ml})$ was immediately raised by adding

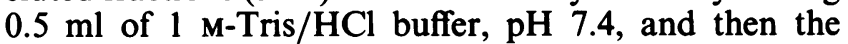
pooled immunoglobulin-containing fractions were dialysed overnight against $0.15 \mathrm{M}-\mathrm{NaCl} / 50 \mathrm{~mm}$-Tris/HCl buffer, pH 7.4. Purified anti-MPO immunoglobulins were immobilized on $\mathrm{CNBr}$-activated Sepharose $(2 \mathrm{mg}$ of anti-MPO $/ \mathrm{ml}$ of gel) and used in the isolation of immunoreactive MPO in human plasma. Before use, anti-MPO-Sepharose was washed with 4 vol. of $0.15 \mathrm{M}-\mathrm{NaCl} / 50 \mathrm{~mm}-\mathrm{Tris} / \mathrm{HCl}$ buffer, $\mathrm{pH} \mathrm{7.4,} \mathrm{and} \mathrm{then}$ with 2 vol. of $1.0 \mathrm{M}-\mathrm{NaCl} / 50 \mathrm{~mm}-\mathrm{Tris} / \mathrm{HCl}$ buffer, $\mathrm{pH} 7.4$, containing $0.1 \%$ (w/v) cetyltrimethylammonium bromide. The affinity-purified anti-MPO antibodies were also used to make a radioimmunoassay for MPO and for the detection of immunoreactive MPO after the protein blotting.

\section{Radioimmunoassay}

The purified anti-MPO immunoglobulins were iodinated by the chloramine-T method (Hunter \& Greenwood, 1962) as described by Olsson et al. (1979). To the glass vial containing $10 \mu \mathrm{l}$ of $\mathrm{Na}^{125}$ I (37 MBq) were added $10 \mu \mathrm{l}$ of $0.5 \mathrm{M}$-potassium phosphate buffer, $\mathrm{pH} 7.4$ and $20 \mu \mathrm{l}$ of anti-MPO $(2 \mathrm{mg} / \mathrm{ml})$ in $0.1 \mathrm{M}$-potassium phosphate buffer, $\mathrm{pH}$ 7.4. The reaction was started by adding $10 \mu \mathrm{l}$ of newly made up chloramine-T (Sigma Chemical Co., St. Louis, MO, U.S.A.) $(1 \mathrm{mg} / \mathrm{ml})$ and stopped after $45 \mathrm{~s}$ by the addition of $10 \mu \mathrm{l}$ of sodium metabisulphite $(2.4 \mathrm{mg} / \mathrm{ml})$. After addition of $20 \mu \mathrm{l}$ of bovine serum albumin $(20 \%, \mathrm{w} / \mathrm{v})$ the reaction mixture was chromatographed on a Sephadex G-100 column $(1 \mathrm{~cm} \times 40 \mathrm{~cm})$ with $\quad 10 \mathrm{~mm}$-EDTA/75 mM- $\mathrm{NaCl} / 50 \mathrm{~mm}$-potassium phosphate buffer, $\mathrm{pH} 7.4$, as eluent. The peak fractions of labelled anti-MPO were pooled and diluted with barbital buffer $[0.1 \mathrm{M}-\mathrm{NaCl} / 50 \mathrm{~mm}$-sodium barbital buffer, $\mathrm{pH} 8.6$, containing $2 \%(\mathrm{w} / \mathrm{v})$ bovine serum albumin] to give 600000 c.p.m. $/ 0.1 \mathrm{ml}$ and stored at $-20^{\circ} \mathrm{C}$.

Polystyrene tubes $(3 \mathrm{ml})$ were coated with $250 \mu \mathrm{l}$ of affinity-purified anti-MPO $(2 \mu \mathrm{g} / \mathrm{ml})$ in Tris-buffered saline $(0.12 \mathrm{M}-\mathrm{NaCl} / 30 \mathrm{~mm}$-Tris/ $\mathrm{HCl}$ buffer, $\mathrm{pH} 7.4)$ and left at room temperature for $24 \mathrm{~h}$. The coated tubes were then washed three times with $0.5 \mathrm{ml}$ of Tris-buffered saline and dried inverted on a filter paper. Both samples and purified MPO standards $(5-100 \mathrm{ng} / \mathrm{ml})$ were diluted in the above-mentioned barbital buffer before $100 \mu \mathrm{l}$ portions were added to the anti-MPO-coated tubes and left at room temperature for $24 \mathrm{~h}$. The tubes were then again washed three times with $0.5 \mathrm{ml}$ of Tris-buffered saline before addition of $100 \mu \mathrm{l}$ of ${ }^{125} \mathrm{I}$-anti-MPO, diluted to 60000 c.p.m. $/ 0.1 \mathrm{ml}$ with the barbital buffer. After $48 \mathrm{~h}$ at room temperature the tubes were washed three times with Tris-buffered saline before the bound radioactivity was determined in a $\gamma$-radiation scintillation counter. All measurements were performed in triplicate.

\section{Polyacrylamide-gel electrophoresis and protein blotting}

Polyacrylamide-gel electrophoresis under non-denaturing conditions with glycerol $(25 \%, \mathrm{w} / \mathrm{v})$ and cetyltrimethylammonium bromide $(0.05 \%, \mathrm{w} / \mathrm{v})$ present both in the gel and in the electrode buffer was performed as described previously (Olsen \& Little, 1983). The peroxidase activity in the gel was detected by the use of $3,3^{\prime}$-diaminobenzidine and $\mathrm{H}_{2} \mathrm{O}_{2}$ (Olsen \& Little, 1979). SDS/polyacrylamide-gel electrophoresis was performed with the Laemmli (1970) system modified as described previously (Olsen \& Little, 1984). The samples were reduced with $1 \%(\mathrm{w} / \mathrm{v})$ 2-mercaptoethanol and then heated for $3 \mathrm{~min}$ on a boiling-water bath before electrophoresis. Protein was detected by staining the gel with Coomassie Brilliant Blue in acetic acid $(10 \%$, $\mathrm{v} / \mathrm{v}) /$ methanol $(25 \%, \mathrm{v} / \mathrm{v})$.

After SDS/polyacrylamide-gel electrophoresis the separated polypeptides were electrophoretically transferred to nitrocellulose, essentially as described by Towbin et al. (1979), by using an electroblot apparatus (Bio-Rad Laboratories, Richmond, CA, U.S.A.) with a

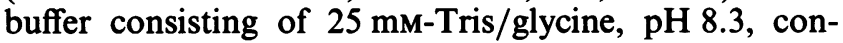
taining $20 \%(\mathrm{v} / \mathrm{v})$ methanol. The transfer was performed by using $130 \mathrm{~V}$ for $4 \mathrm{~h}$ at $10^{\circ} \mathrm{C}$. After the blotting the nitrocellulose sheet was washed for $1 \mathrm{~h}$ at $37^{\circ} \mathrm{C}$ with phosphate-buffered saline $\mathrm{A}(135 \mathrm{~mm}-\mathrm{NaCl} / 3 \mathrm{mM}-\mathrm{KCl} /$ $10 \mathrm{mM}-\mathrm{Na}_{2} \mathrm{HPO}_{4} / \mathrm{KH}_{2} \mathrm{PO}_{4}$ buffer, pH 7.4) containing $5 \%(\mathrm{w} / \mathrm{v})$ non-fat dried milk. The nitrocellulose sheet was then incubated with gentle shaking overnight at $4{ }^{\circ} \mathrm{C}$ in phosphate-buffered saline A containing $0.5 \%$ (w/v) non-fat dried milk and $0.05 \%$ (w/v) Tween 20 (Bio-Rad Laboratories) and affinity-purified anti-MPO immunoglobulins $(12 \mu \mathrm{g} / \mathrm{ml})$. Then after being washed for $2 \mathrm{~h}$ with three changes in phosphate-buffered saline $\mathrm{A}$ containing $0.05 \%$ (w/v) Tween 20 , the nitrocellulose sheet was incubated with affinity-purified goat anti-rabbit immunoglobulin $G$ antibody-horseradish peroxidase conjugate (Bio-Rad Laboratories) diluted 1000-fold with phosphate-buffered saline A containing $0.5 \%(\mathrm{w} / \mathrm{v})$ non-fat dried milk and $0.05 \%(\mathrm{w} / \mathrm{v})$ Tween 20 . After the sheet had then been washed with phosphate-buffered saline A containing $0.05 \%$ (w/v) Tween 20 for $2 \mathrm{~h}$ with three changes, the peroxidase activity on the nitrocellulose sheet was located by $3,3^{\prime}$-diaminobenzidine $/ \mathrm{H}_{2} \mathrm{O}_{2}$, with the concentrations described previously (Olsen \& Little, 1979). After 1-2 min the peroxidase reaction was stopped by repeated washing with water.

\section{Other methods}

Protein concentration was determined by the method of Bradford (1976) by using the micro method of the Bio-Rad protein assay kit (Bio-Rad Laboratories) with purified granulocyte MPO as standard.

Peroxidase activity was measured and expressed as previously reported (Olsen \& Little, 1981).

Ultrafiltration was carried out in Diaflo equipment (Amicon Corp., Lexington, KY, U.S.A.) with a PM-10 membrane.

\section{RESULTS}

\section{Radioimmunoassay}

MPO concentration was determined by incubating diluted samples in anti-MPO-coated polystyrene tubes with subsequent measurement of the binding of ${ }^{125} \mathrm{I}$ anti-MPO to the tubes. Purified MPO from human granulocytes was used as standard (Fig. 1). Non-specific binding of ${ }^{125}$ I-anti-MPO to the anti-MPO-coated tubes in the absence of MPO was approx. $2.5 \%$ of the total radioactivity added. This control was included when radioimmunoassay was performed, and the radioactivity values obtained for the standards and unknown samples were adjusted accordingly. By this method, the concentration of plasma MPO was estimated to be $113 \mu \mathrm{g} / \mathrm{l}$, a 


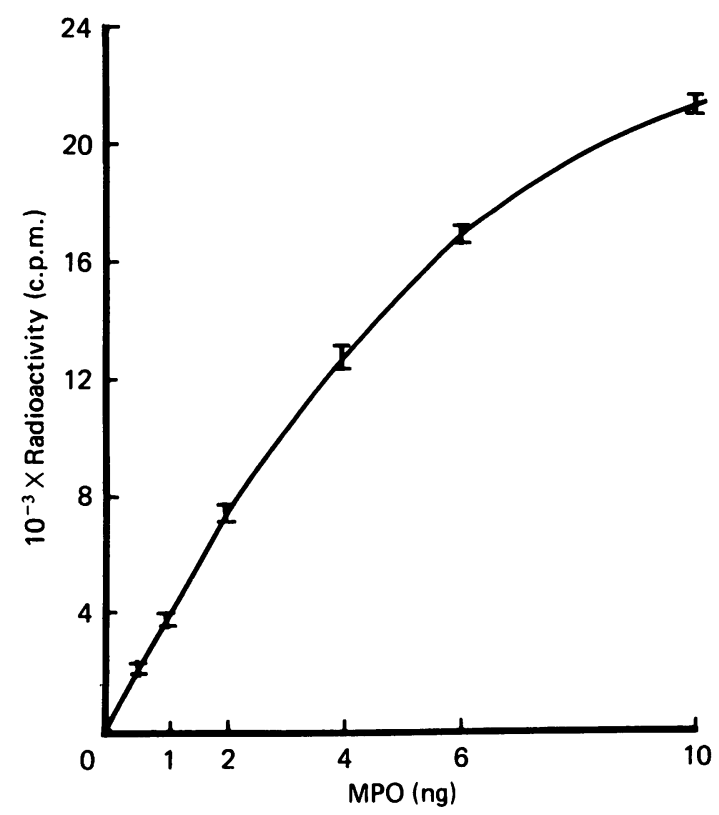

Fig. 1. Standard curve for radioimmunoassay of plasma MPO

Purified granulocyte MPO was used as standard. The bars indicate mean standard deviation.

value similar to those reported elsewhere (Olsson et al., 1979; Venge et al., 1984).

\section{Isolation of immunoreactive MPO}

Ion-exchange chromatography. Thawed plasma $(2.8$ litres) was centrifuged $(8000 \mathrm{~g}$ for $15 \mathrm{~min})$ to remove fat and then adjusted to $\mathrm{pH} 8.1$ by adding $56 \mathrm{ml}$ of $1 \mathrm{M}$-Tris/HCl buffer, $\mathrm{pH}$ 8.2. The plasma was then mixed with $700 \mathrm{ml}$ (packed volume) of CM-Sephadex C-50 previously equilibrated against $20 \mathrm{mM}$-Tris/ $\mathrm{HCl}$ buffer, $\mathrm{pH} \mathrm{8.2,} \mathrm{and} \mathrm{incubated} \mathrm{overnight} \mathrm{at} 4{ }^{\circ} \mathrm{C}$ in a 5-litre bottle with continuous agitation ( $30 \mathrm{rev} . / \mathrm{min})$. The mixture was then poured into a column $(5.5 \mathrm{~cm}$ diameter $)$ and washed with $20 \mathrm{~mm}$-Tris/ $\mathrm{HCl}$ buffer, $\mathrm{pH} 8.2$, until the $A_{280}$ of the eluate was less than 0.02 . The column was then eluted with the same buffer but containing $1.0 \mathrm{M}-\mathrm{NaCl}$. Fractions $(100 \mathrm{ml})$ were collected, and the $A_{280}$ and immunoactive MPO were measured (results not shown). Fractions containing the eluted immunoactivity were pooled and adjusted to $0.1 \%(\mathrm{w} / \mathrm{v})$ cetyltrimethylammonium bromide before being concentrated to $28 \mathrm{ml}$ by ultrafiltration.

Immunoaffinity chromatography. The concentrated eluate from the previous step was applied to a column $(12 \mathrm{ml})$ of Sepharose-immobilized affinity-purified antiMPO immunoglobulin $(1 \mathrm{ml} / \mathrm{min})$ at $4{ }^{\circ} \mathrm{C}$. The column was then washed with $1.0 \mathrm{M}-\mathrm{NaCl} / 50 \mathrm{~mm}-\mathrm{Tris} / \mathrm{HCl}$ buffer, $\mathrm{pH} 7.4$, containing $0.1 \%(\mathrm{w} / \mathrm{v})$ cetyltrimethylammonium bromide and subsequently eluted with $1.0 \mathrm{M}$ $\mathrm{NaCl} / 50$ mM-sodium acetate buffer, $\mathrm{pH} 3.6$, containing $5 \mathrm{M}$-urea and $0.1 \%(\mathrm{w} / \mathrm{v})$ cetyltrimethylammonium bromide. Fractions $(5 \mathrm{ml})$ were collected throughout and tested for $A_{280}$ and peroxidase activity (Fig. 2). Upon collection, the $\mathrm{pH}$ of each fraction was raised by the addition of $0.5 \mathrm{ml}$ of $1.0 \mathrm{M}$-Tris/ $\mathrm{HCl}$ buffer, $\mathrm{pH} 7.4$. After the removal of samples for use in radioimmunoassay, fractions $28-35$ were pooled and then concentrated by ultrafiltration, followed by dilution (20-fold) with $1.0 \mathrm{M}-\mathrm{NaCl} / 50 \mathrm{~mm}-\mathrm{Tris} / \mathrm{HCl}$ buffer, $\mathrm{pH} 7.4$, containing $0.1 \%(\mathrm{w} / \mathrm{v})$ cetyltrimethylammonium bromide. The concentration and dilution procedure were repeated once more, and the end product was finally concentrated. The results of this two-step purification procedure are shown in Table 1.

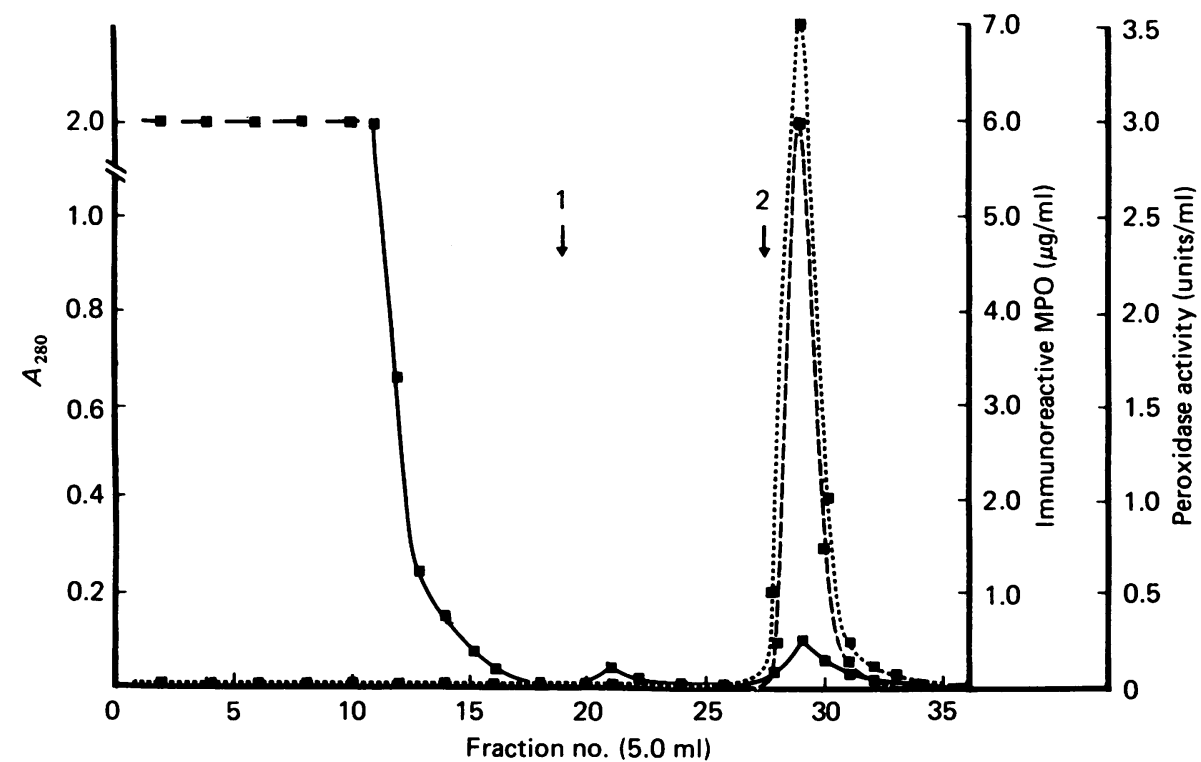

Fig. 2. Immunoafinity chromatography of plasma MPO

Concentrated plasma MPO from the ion-exchange step was purified on anti-MPO-Sepharose. After application of the plasma MPO, the column was washed with $1.0 \mathrm{M}-\mathrm{NaCl} / 50 \mathrm{~mm}-\mathrm{Tris} / \mathrm{HCl}$ buffer, $\mathrm{pH} 7.4$, containing $0.1 \%$ cetyltrimethylammonium

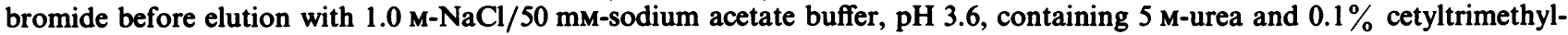
ammonium bromide. The first arrow indicates a 30 min pause in the washing procedure, and the second arrow points to the start of the elution. The collected fractions $(5 \mathrm{ml})$ were tested for protein $\left(A_{280},-\right)$, peroxidase activity $(---)$ and MPO immunoactivity (------). 
Table 1. Isolation of human plasma MPO

For experimental details see the text.

\begin{tabular}{lcccrr}
\hline Isolation step & $\begin{array}{c}\text { Volume } \\
(\mathrm{ml})\end{array}$ & $\begin{array}{c}\text { Total MPO } \\
(\mu \mathrm{g})\end{array}$ & $\begin{array}{c}\text { Total protein } \\
(\mathrm{mg})\end{array}$ & $\begin{array}{c}\text { Recovery } \\
(\%)\end{array}$ & $\begin{array}{c}\text { Purification } \\
(\text { fold })\end{array}$ \\
\hline Plasma & 2850 & 322 & 42000 & 100 & 63 \\
CM-Sephadex C-50 ion-exchange & 1200 & 204 & 1200 & 22 & 8260 \\
Immunoaffinity chromatography & 4.5 & 57 & 0.9 & 18 & 82 \\
\hline
\end{tabular}

\section{Properties of the purified immunoreactive plasma MPO}

The peroxidase activity in the final product, as measured by the guaiacol method, was 5.7 units $/ \mathrm{ml}$, giving a specific activity of 28 units $/ \mathrm{mg}$ of protein. Expressed relative to the amount of immunoreactive MPO the value can be calculated to be 450 units $/ \mathrm{mg}$. However, Table 1 also shows that only about $6.3 \%$ of the protein in the product is immunoreactive MPO.

To dissociate the antigen-antibody complex in the immunoaffinity chromatography it was necessary to use a $\mathrm{pH}$ of 3.6. As shown in Fig. 3, purified human granulocyte MPO is inactivated at such a low $\mathrm{pH}$, with $40 \%$ decrease in activity after $10 \mathrm{~min}$ incubation. At the times indicated, samples were taken from the incubation and the $\mathrm{pH}$ was raised by adding 0.1 vol. of $1.0 \mathrm{M}$-Tris $/ \mathrm{HCl}$ buffer, $\mathrm{pH} 8.0$, before the residual activity was measured. No subsequent inactivation was then observed. Using a slightly higher $\mathrm{pH}$ (pH 4.0) in the elution buffer gave a recovery of immunoreactive material from the affinity column of only about $2 \%$.

The Soret-region absorption spectrum of the purified plasma MPO (Fig. 4) shows a maximum at $422 \mathrm{~nm}$. The ratio between the absorbance at $422 \mathrm{~nm}$ and at $280 \mathrm{~nm}$ was 0.15 . Purified granulocyte MPO at $\mathrm{pH} 5.6 \mathrm{had}$ an absorption maximum at $432 \mathrm{~nm}$, but after $30 \mathrm{~min}$ in the elution buffer this peak had shifted to $424 \mathrm{~nm}$ with a simultaneous decrease in the absorption of approx. $10 \%$.

\section{Polyacrylamide-gel electrophoresis and protein blotting}

The purified immunoreactive MPO, together with MPO and eosinophil peroxidase isolated from human granulocytes as described previously (Olsen \& Little, 1983), were subjected to analytical polyacrylamide-gel electrophoresis and stained for peroxidase activity (Fig. 5). The MPO isolated from human plasma is detected as two strong and two weaker peroxidase activities by this electrophoresis system (lane 3). All four detected activities have mobilities very similar to that of myeloperoxidase isolated from human granulocytes (lane 2).

The purified immunoreactive MPO from plasma and the two peroxidases from human granulocytes were also analysed by SDS/polyacrylamide-gel electrophoresis with subsequent protein blotting on nitrocellulose paper (Fig. 6). Protein staining after SDS/polyacrylamide-gel electrophoresis shows the presence of several polypeptides in the purified plasma MPO (lane 4). The apparent $M_{\mathrm{r}}$ values of the more intensely stained bands are 86000 , 57000,52000 and 15000 and the more weakly stained bands have $M_{\mathrm{r}}$ values of approx. 42000, 34000 and

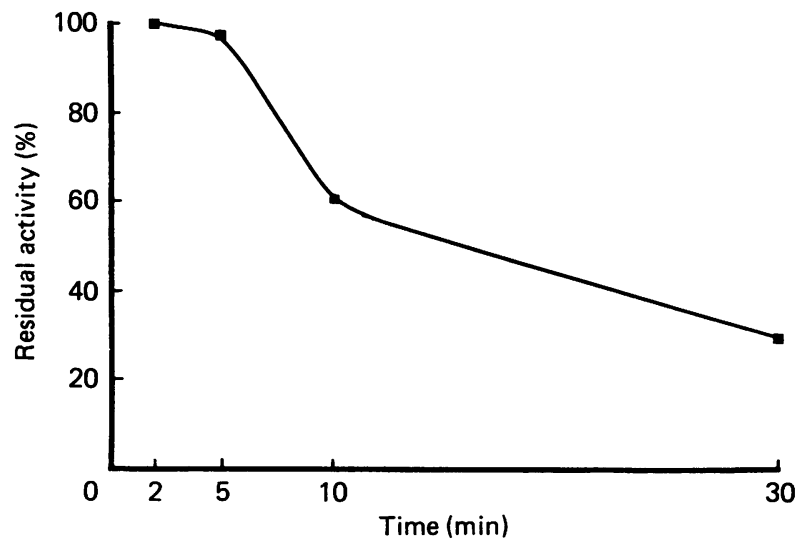

Fig. 3. Stability of granulocyte MPO in the elution buffer of the immunoaffinity chromatography

The Figure shows the decrease in enzyme activity of granulocyte MPO in $1.0 \mathrm{M}-\mathrm{NaCl} / 50 \mathrm{~mm}$-sodium acetate buffer, $\mathrm{pH} 3.6$, containing $5 \mathrm{~m}$-urea and $0.1 \%$ cetyltrimethylammonium bromide at $4{ }^{\circ} \mathrm{C}$. At the times indicated the $\mathrm{pH}$ of the incubation mixture was raised by adding 0.1 vol. of $1.0 \mathrm{M}$-Tris/ $\mathrm{HCl}$ buffer, $\mathrm{pH} 8.0$, and the residual activity was measured.

28000. For comparison, the polypeptide patterns of granulocyte MPO and eosinophil peroxidase are shown in lanes 3 and 7 respectively.

Lanes 2, 5 and 6 show respectively the nitrocellulose blot of granulocyte MPO, plasma MPO and eosinophil peroxidase after incubation with anti-MPO immunoglobulins and horseradish peroxidase-labelled secondary antibodies as described in the Materials and methods section. Both the major polypeptide forms of granulocyte MPO $\left(M_{\mathrm{r}} 57000\right.$ and 15000) and the weak double band $\left(M_{\mathrm{r}} 40000-41000\right)$ react strongly with the anti-MPO immunoglobulins (lane 2). In addition, strongly antigenic material with $M_{\mathrm{r}}$ approx. 25000 and just faintly discernible with the protein stain is detected. As can be seen from lane 6, the affinity-purified anti-MPO immunoglobulins also have affinity for the large subunit of eosinophil peroxidase $\left(M_{\mathrm{r}} 50000\right)$ but not apparently for the low- $M_{\mathrm{r}}$ subunit (apparent $M_{\mathrm{r}}$ 15000). Lane 5 shows the nitrocellulose blot of the purified plasma MPO, and it can be seen that the anti-MPO immunoglobulins react strongly with the polypeptides of $M_{\mathrm{r}} 57000$ and 15000 and also with the high- $M_{\mathrm{r}}$ polypeptide $\left(M_{\mathrm{r}} 85000\right)$. Faintly detectable immunoreactions can also be seen at positions corresponding to $M_{\mathrm{r}} 52000,41000$ and 28000 . 


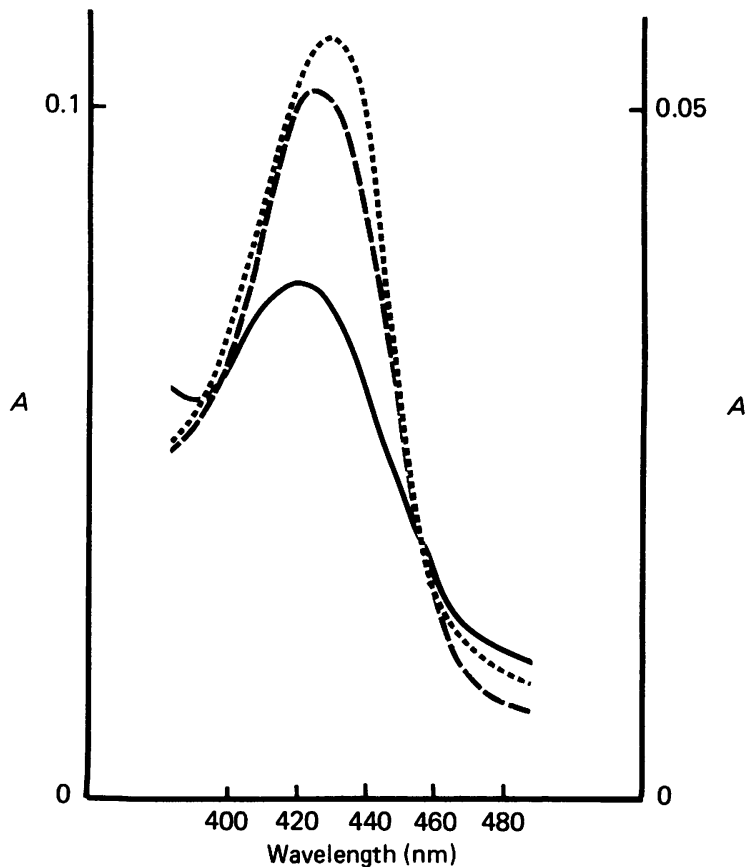

Fig. 4. Soret-region absorption spectra of the plasma MPO and granulocyte MPO

The Figure shows the Soret-band absorption spectra of plasma MPO (12 $\mu \mathrm{g}$ of immunoreactive $\mathrm{MPO} / \mathrm{ml}$ ) and granulocyte MPO $(0.1 \mu \mathrm{g} / \mathrm{ml})$. - Plasma MPO at pH 7.4; ------, granulocyte MPO at pH 4.5 ; - - , granulocyte MPO after $30 \mathrm{~min}$ in the affinity-chromatography elution buffer. The left-hand ordinate refers to granulocyte MPO, whereas the right-hand ordinate refers to plasma MPO.

\section{DISCUSSION}

Immunoreactive MPO from pooled fresh normal human plasma was purified some 8000 -fold with $18 \%$ recovery by ion-exchange and immunoaffinity chromatography. In the final product only $6-7 \%$ of the protein is accounted for by immunoreactive MPO. SDS/polyacrylamide-gel electrophoresis (Fig. 6, lane 4) of the final product shows the presence of some non-immunoreactive polypeptides arising from the concomitant elution of protein bound non-specifically to the immunoaffinity gel.

The immunoreactive material eluted from the affinity column has a specific activity of just 28 units of peroxidase activity $/ \mathrm{mg}$ of total protein, which is only about $1.5 \%$ of the specific activity for purified MPO from granulocytes (Olsen \& Little, 1983). Expressed relative to the amount of immunoreactive MPO present, the specific activity is 450 units $/ \mathrm{mg}$, i.e. approx. $25 \%$ of the value for pure granulocyte enzyme. This suggests that some of the immunoreactive MPO from plasma might not be fully catalytically functional. As shown by the electrophoresis (Figs. 5 and 6), the immunoreactive plasma MPO seems to contain precursor and incorrectly processed forms of the enzyme. However, another important contributing factor to the low specific activity is denaturation during elution from the affinity column. To elute immunoreactive MPO from this column it was necessary to use a pH that partly inactivates the granulocyte enzyme. This low $\mathrm{pH}$ could reasonably be expected to cause about $50 \%$ inactivation of plasma MPO activity.
Fig. 5. Non-denaturing polyacrylamide-gel electrophoresis of purified plasma MPO

Approx. $2.8 \mu \mathrm{g}$ of immunoreactive plasma MPO was applied to lane 3, and purified granulocyte MPO $(0.7 \mu \mathrm{g})$ and purified eosinophil peroxidase $(0.7 \mu \mathrm{g})$ were applied to lanes 2 and 1 respectively. Electrophoresis was then performed under non-denaturing conditions, after which the gels were stained for peroxidase activity. Further details are given in the Materials and methods section.

The absorption spectrum of the purified plasma MPO in the Soret region shows a peak at $422 \mathrm{~nm}$ (Fig. 4). When the granulocyte enzyme was incubated with the elution buffer from the affinity chromatography, the Soret-band maximum shifted from $432 \mathrm{~nm}$ to $424 \mathrm{~nm}$. Odajima \& Yamazaki (1972) reported a similar shift in the Soret-band maximum for MPO upon acidification. From the data in Fig. 4, it can be calculated that for the $\mathrm{pH}$ 3.6-exposed enzyme forms the plasma MPO has an absorbance at $422 \mathrm{~nm}$ relative to the amount of immunoreactive MPO of $A_{1}^{1 \%} \mathrm{~cm}=30$, a value significantly higher than that for the highly purified granulocyte enzyme $\left(A_{1}^{1 \%} \mathrm{~cm}=12\right)$. This would suggest that radioimmunoassay underestimates the concentration of the plasma MPO forms.

Purified plasma MPO was analysed by non-denaturing polyacrylamide-gel electrophoresis, and as shown in Fig. 5 two main activities are seen, one with a mobility similar to that of granulocyte MPO and another that is slightly more retarded.

The results in Fig. 6 from the SDS/polyacrylamide-gel electrophoresis and protein blotting of the purified plasma MPO show that the two polypeptides of strongest antigenicity have apparent $M_{\mathrm{r}}$ values in this system of 


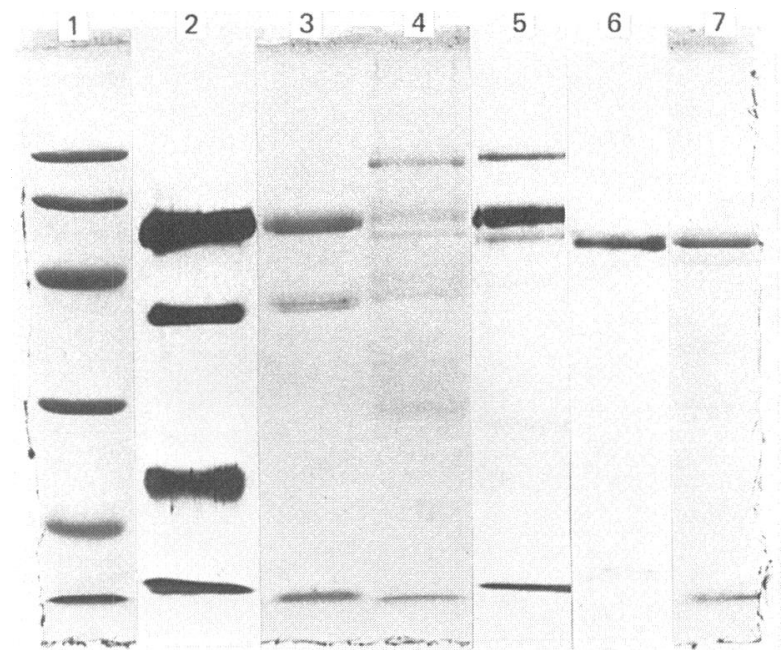

Fig. 6. SDS/polyacrylamide-gel electrophoresis and protein blotting of purified plasma MPO

Electrophoresis and protein blotting were performed as described in the Materials and methods section. Two slab gels were run; one was stained for protein with Coomassie Brilliant Blue, and the other was used in protein blotting on to nitrocellulose paper and immunostained with anti-MPO and horseradish peroxidase-conjugated secondary antibodies followed by peroxidase staining. The protein-stained gel and the peroxidase-stained nitrocellulose paper were both photographed. The various tracks in the photographs were then excised and assembled as shown in the Figure. Lane 1 shows protein staining of standard proteins: phosphorylase $b$, bovine serum albumin, ovalbumin, carbonic anhydrase, soya-bean trypsin inhibitor and lactalbumin $\left(M_{\mathrm{r}}\right.$ values $94000,67000,43000,30000$, 20000 and 14400 respectively). Lanes 2 and 3 refer to granulocyte MPO (5 $\mu \mathrm{g}$ and $16 \mu \mathrm{g}$ samples) with immunostaining and protein staining respectively. Lanes 4 and 5 refer to plasma MPO (16 $\mu \mathrm{g}$ and $5 \mu \mathrm{g}$ samples) with protein staining and immuno-staining respectively. Lanes 6 and 7 refer to eosinophil peroxidase (5 $\mu \mathrm{g}$ and $12 \mu \mathrm{g}$ samples) with immuno-staining and protein staining respectively.

57000 and 15000 . These are identical with those of the two subunits of the mature MPO. In addition, a polypeptide of $M_{\mathrm{r}}$ approx. 85000 with affinity for the anti-MPO immunoglobulin is present in the plasma MPO. This may be the precursor form of the enzyme. Studying biosynthesis of MPO in the promyelocyte cell line HL-60, several investigators have reported the presence of such a precursor (Yamada, 1982; Hasilik et al., 1984; Olsson et al., 1984; Koeffler et al., 1985). When comparing the relative intensities of the immunocolouring and the protein-stained counterparts, the weak immunostaining of the proposed precursor is very probably due to the well-documented difficulties in the electro-blotting of high- $M_{\mathrm{r}}$ polypeptides (reviewed by Gershoni \& Palade, 1983).

The protein blotting of the granulocyte MPO shows the presence of one strong immunoreactive band $\left(M_{\mathrm{r}} 25000\right)$ with no apparent corresponding protein-stained band. This immunoreactive band coincides with the carbohydrate-rich band present in the granulocyte MPO (Olsen \& Little, 1984) and the [ $\left.{ }^{32} \mathrm{P}\right]$ phosphate-labelled endo- $\beta$ - $N$-acetylglucosaminidase $H$-sensitive band of myeloperoxidase in HL-60 cells (Hasilik et al., 1984). This result suggests the presence of carbohydrate antigenic determinants on the granulocyte MPO.

When the granulocyte MPO and eosinophil peroxidase were blotted, the same amounts of the purified enzymes were used and the results show that the anti-MPO immunoglobulins react weakly with eosinophil peroxidase. Öberg et al. (1983) have reported a weak cross-reactivity between MPO and eosinophil peroxidase with antiserum against MPO. In the purified plasma MPO, an immunoreactive band of similar mobility to that of the large subunit of eosinophil peroxidase is seen.

In normal plasma the presence of large amounts of mature polypeptides and active enzyme is rather surprising, since in cultures of HL-60 cells only the precursor is secreted (Yamada, 1982; Hasilik et al., 1984; Olsson et al., 1984). Apparently, also, normal bonemarrow cells secrete only the precursor form (Olsson et al., 1984). In addition, Zühlsdorf et al. (1983) reported that the two lysosomal enzymes $\beta$-hexosaminidase and cathepsin D in serum of normal subjects are present almost exclusively in the precursor form. The source of the mature active MPO in donated human plasma might be damaged or stimulated granulocytes.

Plasma was provided by the Blood Bank, University Hospital, Tromsø. The work was supported financially by the Erna and Olav Aakre Foundation. T. K. S. is a recipient of a student grant from the Norwegian Research Council for Science and the Humanities.

\section{REFERENCES}

Andersen, M. R., Atkin, C. L. \& Eyre, H. J. (1982) Arch. Biochem. Biophys. 214, 273-283

Andrews, P. C. \& Krinsky, N. I. (1981) J. Biol. Chem. 256, $4211-4218$

Bainton, D. F., Ullyot, J. L. \& Farquhar, M. G. (1971) J. Exp. Med. 134, 907-934

Bentwood, B. J. \& Henson, P. M. (1980) J. Immunol. 124, 855-862

Bradford, M. M. (1976) Anal. Biochem. 78, 248-254

Bradley, P. P., Christensen, R. D. \& Rothstein, G. (1982) Blood 60, 618-622

Erickson, A. H. \& Blobel, G. (1979) J. Biol. Chem. 254, 11771-11774

Gershoni, J. M. \& Palade, G. E. (1983) Anal. Biochem. 131, $1-15$

Hansen, N. E., Malmquist, J. \& Thorell, J. (1975) Acta Med. Scand. 198, 437-443

Hasilik, A. \& Neufeld, E. F. (1980) J. Biol. Chem. 255, 4937-4945

Hasilik, A., Voss, B. \& von Figura, K. (1981) Exp. Cell Res. 133, 23-30

Hasilik, A., Pohlmann, R., Steckel, G., Gieselmann, V., von Figura, K., Olsen, R. \& Waheed, A. (1983) in Protein Synthesis (Abraham, A. K., Eikhom, T. S. \& Pryme, I. F., eds.) pp. 349-370, Humana Press, Clifton

Hasilik, A., Pohlmann, R., Olsen, R. L. \& von Figura, K. (1984) EMBO J. 3, 2671-2676

Henson, P. M. (1971) J. Immunol. 107, 1535-1557

Hunter, W. M. \& Greenwood, F. C. (1962) Nature (London) $194,495-496$

Imort, M., Zühldsorf, M., Feige, U., Hasilik, A. \& von Figura, K. (1983) Biochem. J. 214, 671-678

Koeffler, H. P., Ranyard, J. \& Pertcheck, M. (1985) Blood 65, 484-491

Laemmli, U. K. (1970) Nature (London) 227, 680-685 
Malmquist, J. (1972) Scand. J. Haematol. 9, 311-317

Öberg, G. \& Venge, P. (1982) Eur. J. Clin. Invest. 12, 30

Öberg, G., Lindmark, G., Moberg, L. \& Venge, P. (1983) Br. J. Haematol. 55, 701-708

Odajima, T. \& Yamazaki, I. (1972) Biochim. Biophys. Acta 284, 368-374

Olsen, R. L. \& Little, C. (1979) Eur. J. Biochem. 101, 333339

Olsen, R. L. \& Little, C. (1981) Acta Chem. Scand. Ser. B 35, $1-4$

Olsen, R. L. \& Little, C. (1982) Biochem. J. 207, 613-616

Olsen, R. L. \& Little, C. (1983) Biochem. J. 209, 781-787

Olsen, R. L. \& Little, C. (1984) Biochem. J. 222, 701-709

Olsson, I., Olofsson, T. \& Odeberg, H. (1972) Scand. J. Haematol. 9, 483-491

Olsson, I., Olofsson, T., Ohlsson, K. \& Gustavsson, A. (1979) Scand. J. Haematol. 22, 397-406

Received 16 December 1985/30 January 1986; accepted 1 April 1986
Olsson, I., Persson, A.-M. \& Strömberg, K. (1984) Biochem. J. 223, 911-920

Page, R. C., Davies, P. \& Allison, A. C. (1978) Int. Rev. Cytol. 52, 119-157

Skudlarek, M. D. \& Swank, R. T. (1981) J. Biol. Chem. 256, 10137-10144

Sly, W. S. \& Fischer, H. D. (1982) J. Cell. Biochem. 18, 67-85

Spitznagel, J. K., Dalldorf, F. G., Leffell, M. S., Folds, J. D., Welsh, I. R. H., Cooney, M. H. \& Martin, L. E. (1974) Lab. Invest. 30, 774-785

Towbin, H., Staehelin, T. \& Gordon, J. (1979) Proc. Natl. Acad. Sci. U.S.A. 76, 4350-4354

Venge, P., Foucard, T., Henriksen, J., Håkansson, L. \& Kreuger, A. (1984) Clin. Chim. Acta 136, 121-130

Yamada, M. (1982) J. Biol. Chem. 257, 5980-5982

Zühlsdorf, M., Imort, M., Hasilik, A. \& von Figura, K. (1983) Biochem. J. 213, 733-740 